\section{O PESSIMISMO MORAL SCHOPENHAUERIANO:}

\author{
ORIGEM, SIGNIFICADO E ALCANCE
}

\author{
SCHOPENHAUER'S MORAL PESSIMISM: \\ ORIGIN, MEANING AND REACH
}

\section{DAX MORAES ${ }^{1}$}

(UFRN, Brasil)

\begin{abstract}
RESUMO
"Pessimismo moral" é uma expressão pela qual se pode compreender a tese schopenhaueriana sobre a imutabilidade do caráter, na medida em que declara impossível qualquer espécie de aprimoramento moral, restando apenas a possibilidade de se adaptar o comportamento considerados os limites do egoísmo natural. Por sua vez, trata-se de uma consequência de problemas epistemológicos levantados pela crítica kantiana da razão, a qual foi radicalizada por Schopenhauer. Todavia, o "pessimismo moral" deve ser considerado como um problema metafísico, não como um problema "prático", podendo ter suas consequências empíricas mais bem analisadas segundo o que se pode denominar "pessimismo antropológico". Por meio desta última expressão, não entendemos apenas um juízo acerca na natureza humana, mas acerca dos sofrimentos individuais no conflito com um mundo que ameaça os interesses particulares.
\end{abstract}

Palavras-chave: Pessimismo; Valor; Moralidade; Egoísmo; Caráter

\begin{abstract}
"Moral pessimism" is an expression by which one may understand Schopenhauer's thesis about immutability of character so far as it declares impossible each and every kind of moral enhancement, remaining only attainable some behavior adaptation based on natural egoism. This is otherwise a kind of result of epistemological problems raised by Kantian critique of reason that Schopenhauer carried to its limits. On the other hand, "moral pessimism" is to be faced not as a "practical" problem, but as a metaphysical one and its empirical consequences can be better considered as one may call "anthropological pessimism" once by this expression we mean not only a judgment about human nature alone but individual sufferings facing a world that menaces individual interests.
\end{abstract}

Keywords: Pessimism; Value; Moraliy; Egoism; Character

\section{Metafísica imanente: preâmbulo e fundo epistemológico para o problema da moral}

Para se analisar qualquer aspecto do assim chamado "pessimismo schopenhaueriano" é absolutamente necessário ter em conta sua relação com a filosofia crítica de Kant e a atitude antidogmática que lhe deixa como única alternativa a elaboração de uma metafísica imanente. Esta consistiria em não especular sobre o mundo segundo 
pressuposições acerca do que se encontra além de toda experiência possível, mas investigar os fenômenos naquilo que eles mostram de seu ser para nós e que não pode ser apreendido seguindo-se meramente o fio das conexões causais. Ou seja, em vez de supor algum ser em si independente do mundo como uma causa-primeira ou fundamento, ater-se ao seu modo de faticamente dar-se na tentativa de assim superar o erro decisivo das metafísicas dogmáticas, a saber, a extensão do princípio de causalidade para além do mundo físico (ao qual deve ser aplicado com exclusividade) e a pretensa validação de hipóteses transcendentes à luz do princípio de não contradição. Isso implica uma revisão do que devemos entender por "essência".

É certo que Schopenhauer ainda emprega o termo "existentia" no sentido tradicional de "subsistência", "substância", "suporte de propriedades" [...]. Por outro lado, merece relevo a quase imperceptível novidade no que diz respeito à noção de "essentia": sempre que lemos as afirmações de que o mundo e tudo que nele há é vontade, ou seja, que vontade é a essência de todas as coisas, tendemos a interpretar, sob influência da tradição metafísica, que Schopenhauer esteja apontando a Vontade como uma propriedade universal dada pertinente a todos os entes; em uma palavra, como o Ser [...]. Percebe-se, no entanto, que outra coisa bem diferente está sendo dita: que o mundo, em sua totalidade, é segundo uma vontade. Que a Vontade é a coisa em si significa, então: o que representamos (o ente) não é nada mais do que aquilo que se mostra em relação à vontade que nós mesmos somos. Em outros termos: a Vontade é o fundo do ente segundo o qual o ente sempre se mostra como tal, isto é, como representação. (MORAES, 2010a, p. 39)

Diz Schopenhauer (2005, §63, p. 449), de modo curto e claro: “Tal qual a Vontade é, é o mundo". Essa compreensão da essência do mundo e do que nele há traz implicações decisivas para um caso particular do que denomino neste artigo "pessimismo moral", qual seja, que não temos escolha quanto ao fato de já sermos sempre uma vontade determinada a ser este indivíduo que cada um de nós é, ou melhor, que não temos acesso ao porquê dessa decisão e, portanto, não nos reconhecemos imputáveis, responsáveis, "culpados" pela nossa existência, mas o somos, tal como Schopenhauer afirma na sequência. Trata-se da defesa de que toda liberdade da vontade se encerra na liberdade de querer ou não querer a vida, querer ou não querer existir, decisão que, uma vez tomada, não por uma inteligência, mas pelo querer ele mesmo, é irrevogável. ${ }^{2}$ Esse caso particular é agora antecipado por seu caráter crucial no que concerne aos limites do poder e do conhecer sobre o querer, limites que podem ser considerados o ponto central do referido pessimismo. 
Que o problema da relação essência-existência se reflete na incompreensão geral do que está em jogo na Metafísica da Ética de Schopenhauer, ele mesmo o reconhece no capítulo 37 dos complementos a $O$ mundo como vontade e representação (MVR II), dizendo que

\begin{abstract}
a expressão "essência e existência do ser humano" contém o gérmen para a controvérsia se o assunto principal é a essência, isto é, os caracteres, ou a existência, isto é, o destino, o acontecimento, a ação. Ademais, ambas encontram-se tão intimamente amalgamadas entre si que até se pode separar seu conceito, não sua exposição. Pois somente as circunstâncias, os destinos, os acontecimentos levam os caracteres à exteriorização da própria essência, e apenas dos caracteres origina-se a ação, da qual procedem os acontecimentos. Decerto na exposição pode-se destacar mais um ou o outro lado [...]. (SCHOPENHAUER, 2015, p. 519)
\end{abstract}

Ou seja, essência e existência são, para Schopenhauer, dois lados da mesma moeda, a Vontade e suas configurações fenomenais segundo o princípio de razão, e isso não pode ser negligenciado ainda que a exposição exija que se faça abstração dessa unidade de ser e agir mediado por circunstâncias. Pode-se abordar a questão a partir da ação no sentido de reconduzi-la ao ser, reconhecendo-a como manifestação no tempo e espaço de um caráter atemporal, ou a partir do ser, como aquilo que em verdade é livre e se manifesta como atos da vontade livre, aparecendo como determinado por motivos que são o princípio de razão de todo agir humano. Essa tentativa de conciliação entre liberdade da vontade e determinismo das ações, empreendida pela recusa do dualismo que abstratamente separa essência e existência como podendo ser independentes um do outro traz consigo sérios problemas de interpretação a que deveremos retornar adiante. Nessas considerações introdutórias, contudo, o que vale destacar é que aí se trata de uma consequência da crítica da razão, pela qual é epistemologicamente inválido supor, para o mundo e tudo o que há nele, um criador ou uma causa-primeira qualquer, restando apenas a consideração de que cada ente no mundo não seja senão o modo de aparição (Erscheinung) do que é em si mesmo sua própria obra, por livre vontade. Que isso não consiste em uma tese arbitrária e desprovida de evidência é aquilo que Schopenhauer busca defender. Para tanto, o ponto de partida de Schopenhauer é o estabelecimento de sua própria teoria do conhecimento, inspirada na de Kant, mas não como mera repetição desta, e sim como revisão profunda, como que pretendendo superar o mestre. Com isso, a noção mesma de "coisa-em-si" deve ser reconsiderada. 
A coisa-em-si não pode ser, como pretendera Kant, um objeto transcendente pensável como devendo ser um correlato do fenômeno, pelo menos não em si mesma em sentido estrito. A possibilidade da coisa-em-si, para Schopenhauer, é antes encontrada na imanência, no sentimento íntimo do querer/não-querer não condicionado pelo intelecto e suas formas. Há, desse modo, uma importantíssima ressalva com relação à cognoscibilidade da coisa-em-si, que não é cognoscível nela, mas em mim e a partir de $\operatorname{mim}^{3}$

Isso quer dizer que, para Schopenhauer, a coisa-em-si, tal como pode ser tematizada, isto é, abstratamente representada no discurso filosófico, ou mesmo sentida em mim, consiste no quê se faz visível, enquanto se faz visivel para a inteligência, ou seja: a objetivação, a positividade daquilo que, a certa altura, Schopenhauer expõe como Vontade, mas da qual nada se pode dizer fora da relação objetal em que me encontro na condição de sujeito. A Vontade afirmada, manifesta, faz-se objeto; a não-afirmada resta como mistério. ${ }^{4}$ Como isso - acaso se possa denominar metaforicamente um "isso" - é fora da relação, se é fora dela ou por que, não se pode dizer, não apenas porque não se sabe como também porque não há palavras para tal, derivadas que são do mundo percebido. Logo, a negação da Vontade só é perceptível negativamente como uma afirmação que se retraiu; o silêncio da Vontade se mostra apenas como um calar naquele que até então se podia ouvir. Lemos o seguinte em uma carta de Schopenhauer a Becker, com a data 21 de agosto de 1852:

A minha filosofia não fala de um mundo de fábulas, mas deste mundo: ou seja, ela é imanente, não transcendente. Ensina o que é o fenômeno e o que é a coisa-em-si. Esta, porém, é coisa-em-si apenas relativamente, em sua relação com a aparência; e esta só é aparência com relação à coisa-em-si. É, ademais, um fenômeno cerebral. Portanto, o que venha a ser a coisa-em-si fora dessa relação eu não o disse, pois não o sei; nela, todavia, é a vontade de viver. [...] O que então possa ser isso que conhecemos somente como vontade de viver e núcleo dessa aparência, fora da mesma, quando não o é mais ou não o é ainda [i.e. não afirmada], consiste em um problema transcendente para cuja solução as formas do nosso intelecto, funções de um cérebro destinado ao serviço da aparência individual da vontade, não são adequadas para captar e pensar. (SCHOPENHAUER apud CIRACÌ, 2017, p. 107)

Em virtude disso, há um caminho permanentemente barrado para o intelecto e para o que nele se ampara, razão mesma pela qual não se pode estabelecer entre o conhecido e 
o sentido e a coisa-em-si nenhuma espécie de relação ou critério de justificação para a sua possibilidade de ser, nem mesmo o princípio de não contradição.

\begin{abstract}
Não pode haver princípio algum em consequência do qual o mundo, com todos os seus fenômenos, primeiro existiria. [...] O princípio de razão explica as ligações dos fenômenos, não os fenômenos mesmos. Portanto, a filosofia não pode daí partir em busca de uma causa efficiens ou de uma causa finalis do mundo inteiro. A minha filosofia, ao menos, de modo algum investiga de onde veio o mundo e para que existe. O por que está subordinado ao quê [...]. (SCHOPENHAUER, 2005, §15, p. 136-137)
\end{abstract}

Não há razão suficiente última sequer para que sejamos. A passagem citada pode induzir a imprecisão de se tentar falar do que se encontra aquém do princípio de razão como se de fato falássemos disso por meio desse "quê". A coisa-em-si, a vontade de viver, exigiriam ser escritas por Schopenhauer entre aspas - pena não lhe ter ocorrido fazê-lo. Algo aqui deve ser bem entendido: a causalidade eficiente natural, a determinação interna agindo na constituição de organismos, tudo é válido apenas para o mundo fenomenal, relativo a nós, o mundo das relações, o mundo da pluralidade submetida ao princípio de individuação, manifesto no intelecto segundo as formas da representação. "Coisa alguma no mundo possui uma causa absoluta e geral de sua existência, mas apenas uma causa a partir da qual existe exatamente aqui, exatamente agora. [...] Portanto, toda causa é causa ocasional.” (SCHOPENHAUER, 2005, §26, p. 201) Mas o que daí resulta, deixado de lado um conhecedor absoluto, é que o mundo e tudo que há nele, bem como o próprio sujeito para o qual há mundo, em seu ser possível, permanecem sem fundamento. Eis o que também significa dizer "tudo é Vontade": tudo é manifestação de uma livre autodeterminação, sem causa eficiente e sem causa final, pura espontaneidade.

Tendo eliminado o dualismo, Schopenhauer afirma ser o fenômeno a aparência da coisa-em-si e, enquanto tal, a coisa-mesma tal como é para nós, não nos cabendo procurála em uma transcendência. A crítica da razão, em sua luta contra o realismo dogmático, especialmente para evitar a queda no ingênuo ceticismo que pretende jogar fora a transcendência agarrando-se à matéria, nutre em si o germe da definitiva crise dos fundamentos e do niilismo. Ainda que assuma a realidade empírica, coloca um limite insuperável para sua completa inteligibilidade. Diante disso, Kant quis dar um passo atrás: "Para, no entanto, dar a esse conceito [de coisa-em-si] validade objetiva (possibilidade real, já que a primeira era meramente lógica), algo mais é requerido. Este mais, porém, não 
precisa ser buscado em fontes cognitivas teóricas; ele pode localizar-se em fontes práticas" (KANT, 2013, p. 35, B XXVI, n. 9). Schopenhauer discorda...

\section{Pessimismo moral}

O que Schopenhauer diz na citada carta a Becker tem seu teor expresso também no capítulo 22 dos complementos ao MVR, "Visão objetiva do intelecto". O intelecto não é de modo algum disposto para o conhecimento da "essência em si das coisas e do mundo, que existe independentemente de quem conhece", de maneira que a "percepção permanece um mero ter ciência [Innewerden] das suas relações com as outras coisas, e de modo algum está destinada [bestimmt] a expor uma vez sequer na consciência [Bewußtseyn] de que conhece a essência própria e absolutamente real [das eigentliche, schlechthin reale Wesen] dessas coisas" (SCHOPENHAUER, 2015, p. 343-344). A oportunidade de insistirmos nisso é que Schopenhauer imediatamente passa às implicações morais do obstáculo epistemológico, sem que isso signifique "oferecer validade objetiva para o conceito de coisa-em-si por meio de fontes práticas" - conforme as palavras de Kant citadas há pouco -, como se a filosofia moral pudesse oferecer maior positividade do que teoria do conhecimento. Isso não é possível, pois o conhecimento é o limite e a constatação da coisaem-si como vontade emerge, precisamente, de um saber sobre si na relação com outrem, não do em-si como tal, uma vez que não há conhecido sem conhecedor: o conhecer conhece a si já sempre em meio a... como conhece objetos em relação entre si, sem, portanto, infringir a regra geral de que todo conhecimento é relativo.

Deve-se observar, ademais, que a negligência com relação ao problema epistemológico lançado por Schopenhauer como ponto de partida de sua obra, como os acostamentos da estrada a seguir, tem por efeito privar o restante de seu pensamento das premissas necessárias de que são mera conclusão, conclusão essa comumente evitada a fim de se preservar o "erro inato" de sua exigível correção. Não é correto concluir que o pessimismo moral parta da mera postulação do caráter incorrigível do ser humano, pois a tese da imutabilidade do caráter é uma consequência metafísica necessária dos limites impostos pela crítica da razão, na medida em que o caráter não pode receber uma explicação de natureza causal ou receber um fundamento. Assim sendo, o fundamento da moral e a "possibilidade real da coisa-em-si" não advêm de fontes prático-racionais, mas, 
segundo Schopenhauer, a última é, pelo contrário, consequência da invalidade das categorias do entendimento quando aplicadas ao em-si, enquanto o primeiro tem sua concretude no sentimento de compaixão, compreendida (também) metafisicamente como conhecimento da unidade da Vontade que é em mim e no outro. Para que fique mais claro, que há uma coisa-em-si, que na medida de nosso conhecimento podemos denominar pela palavra "vontade" - não significando uma mera "faculdade da alma", mas um ser-livre incondicionado -, é demonstrado pela imanência em nós e precedência do querer em relação ao intelecto, pelo que se exclui a possibilidade de aquilo que somos ter sido criado, produzido por outro. Justamente por não se poder pensá-lo nem explicar a existência à luz da causalidade e demais leis da razão é que se trata de uma metafísica.

Por sua vez, sem risco de se incorrer em uma petição de princípio, a admissão de uma metafísica é também uma aposta necessária, igualmente feita por Kant a seu modo, ao tomar partido na antinomia entre liberdade e necessidade em vista de uma fundamentação da filosofia moral. Para Schopenhauer, como para Kant, o materialismo ou a restrição à consideração do mundo a partir da Física "teria de ser destrutiva para a ética", sendo o teísmo um meio pelo qual a tradição tentou satisfazer tal necessidade (SCHOPENHAUER, 2015, cap. 17, p. 214). ${ }^{5}$ Não seria de modo algum válido chegar a uma doutrina do caráter inteligível por via meramente psicológica (como faz o próprio Kant) ou por qualquer outra fonte empírica, que não vêm senão como confirmação $a$ posteriori daquela consequência metafísica. Eis a sequência, de volta ao capítulo 22 do MVR II, na qual Schopenhauer discorre sobre o uso prático do intelecto enquanto instrumento da vontade "e, portanto, para a consideração dos motivos":

Isso funciona do mesmo modo na medida em que concebemos o significado metafísico da vida como étic[o], pois, nesse sentido, também, encontramos um homem conhecedor apenas tendo em vista a sua conduta. Tal faculdade de conhecimento, que existe exclusivamente para fins práticos, será, por sua própria natureza, sempre conhecedora apenas das relações das coisas umas com as outras e não da sua natureza interior, de como elas são em si mesmas. (SCHOPENHAUER, 2014a, p. 418)

Dentre as coisas incognoscíveis em si mesmas está o que eu mesmo sou. Muito embora a autoconsciência seja qualitativamente distinta da relação dessa mesma consciência com outras coisas, consistindo em uma visão do próprio interior contrastante com a visão meramente superficial do que se encontra no exterior, trata-se de uma 
consciência sempre em atraso com relação aos atos de vontade imediatamente expressos no indivíduo que sou, como corpo, objeto real, portanto, como uma multiplicidade de atos isolados relacionados entre si em minha representação. Sim, sei de mim mesmo apenas indiretamente, por meio de fatos da minha consciência - enquanto fatos, são simplesmente dados a mim, irreparáveis e ineludíveis.

Conheço minha vontade não no todo, como unidade, não perfeitamente conforme sua essência, mas só em seus atos isolados, portanto no tempo, que é a forma do fenômeno de meu corpo e de qualquer objeto. Por conseguinte, o corpo é condição de conhecimento da minha vontade; logo, propriamente dizendo, não posso de modo algum representar a vontade sem representar meu corpo. (SCHOPENHAUER, 2005, §18, p. $159)^{6}$

Encontro em mim, por experiência, originários sentimentos de querer e não querer, agrado e desagrado. Aquilo que assim se revela em mim é sempre dado a mim a posteriori, muitas vezes até como se não fosse eu mesmo ali, agindo. Por conseguinte, o caráter se revela alheio às minhas deliberações, tornando-se possível, por exemplo, o remorso, definido por Schopenhauer como uma má-consciência relativa ao próprio caráter, ao que se é em si, diferindo do mero arrependimento. Além disso, não apenas a autoconsciência emerge em atraso com relação ao ato de vontade como a própria distinção entre conhecimento de si (interno) supõe a exterioridade, a relação entre a consciência e seus objetos. Dito de outro modo, não apenas o reconhecimento de uma vontade em mim atuante $a$ priori remete à sua afetação pelo que de externo lhe é apresentado pelo intelecto como externo a mim; também sua interioridade é meramente relativa a esses produtos intelectuais, como algo que se dá em mim, à parte do que me rodeia. Nietzsche estava certo ao dizer que a aquisição de consciência produz a interioridade, evento tardio na história da humanidade, rejeitando a tese contrária segundo a qual o homem tem consciência por possuir uma interioridade.

O autoconhecimento é imediato, mas a consciência de algo não o é, assim como o próprio corpo é um objeto imediato, mas mediata é sua percepção consciente. O que sou, o que quero, são meus atos que dirão na medida em que os motivos se apresentem. $\mathrm{O}$ desconhecimento do próprio caráter, por sua vez, faz com que eu interprete mal a determinação dos motivos sobre meus atos ou ainda que distinga equivocadamente os verdadeiros motivos para os mesmos, não apenas julgando-me autônomo como também 
me surpreendendo ao testemunhar atos meus inesperados em meio a circunstâncias aparentemente análogas que, outrora, me faziam agir diferentemente. Para explicá-lo, Schopenhauer chega a fazer referência às palavras de Suárez, dizendo que a causa final não move segundo seu ser real, mas secundo seu ser conhecido, de maneira que não é a ocasião bruta que determina nosso agir como uma lei natural, mas a ocasião mediada pelo intelecto, ou seja: o comportamento pode se alterar de acordo com a experiência sem que isso implique modificação no caráter. As assim chamadas leis naturais são universalmente coercitivas pelo simples fato de que sua ação se dá sobre a matéria privada de conhecimento. No caso do ser humano, a coisa se dá de modo inteiramente diverso: a premeditação e a capacidade de dissimulação obscurecem a expressão do caráter, mas não o alteram, sendo por isso que o mesmo se revela privilegiadamente nas pequenas coisas, não nas grandes. Afinal, "nas coisas mais importantes se está alerta, nas ínfimas, por sua vez, segue, sem demasiada reflexão, a própria natureza" (SCHOPENHAUER, 2003, §118, p. 304). Não é à toa que a negação da Vontade implique uma superação do caráter, i.e. a ausência de uma subjetividade volitiva, desejante, pois ele desaparece para si mesmo quando motivos exteriores deixam de mover a vontade, razão pela qual o corpo pode se tornar insensível e indiferente ao que de outro modo o afetaria.

Antes de prosseguir, é necessário esclarecer em que medida se pode falar de um pessimismo moral aqui. Ele não deve ser considerado minimizado pela possibilidade da sabedoria de vida pela "aquisição de um caráter", ou seja, de a ação se tornar regular mediante o acordo entre os motivos e o ser do agente - a ação já sempre é uma expressão sua consideradas as circunstâncias -, tanto menos pela possibilidade de conformação das ações a leis e convenções externas. Em nenhum dos casos há mudança de caráter e, portanto, não há aprimoramento moral mediante a correção do intelecto. ${ }^{7}$ É sabido que Schopenhauer recusa veementemente a deontologia kantiana, mas ainda assim é possível estabelecer o seguinte paralelo no que tange às perturbadoras limitações que a ética schopenhaueriana impõe às pretensões pedagógicas. Segundo Kant, a ação conforme ao dever não é necessariamente uma ação moral, por dever. Em Schopenhauer, teríamos o seguinte: é possível conformar as ações ao interesse comum, seja pela educação, seja pelas leis, seja pelos costumes, ou mesmo pela força, mas isso não significa poder formar $o$ caráter, sendo, todavia, nisso que consiste a pretensão moralista. $\mathrm{O}$ que se pode obter, pragmaticamente, como alternativa, é a conformação do comportamento mediante o 
oferecimento de contramotivos que tornem desinteressante agir de modo considerado socialmente pernicioso. Essa possibilidade envolve uma série de níveis e considerações de que não posso me ocupar aqui, bastando-nos, porém, enfatizar-se que o otimismo ou pessimismo moral devem dizer respeito exclusivamente à possibilidade ou impossibilidade de produzir uma melhora no caráter, não nos costumes, um aprimoramento do querer que se mostra na ação, pois, caso contrário, não se obtém mais do que uma heteronomia utilitariamente eficaz. Justamente por isso, de modo algum vem ao caso a possibilidade de negação da vontade, já que, nela mesma, implica uma não-ação.

O paralelo com Kant é nesse ínterim relevante, pois serve de ilustração para que se compreenda que a conformidade das ações ao bem geral não pode ser estimada como agir moral, que só o é na medida em que exprime um ato livre e incondicionado que, como tal, não pode ser determinado extrinsecamente. Desse modo, a crítica da razão conduz ao reconhecimento de um incondicionado em nós passível de analogia com o ser em si de todo o resto; em retorno, a impossibilidade de determinação dessa coisa-em-si em geral implica a impossibilidade de conhecimento e ação eficiente sobre nosso próprio ser em si como tal.

Schopenhauer, entretanto, não nega a liberdade das ações - esse é um tópico passível de confusões que exigem elucidação, porém é precisamente aqui que o pessimismo moral oferece como contrapartida uma saída para a contradição inerente a toda teodiceia. ${ }^{8} \mathrm{O}$ que ele nega é que as ações não sejam todas determinadas com absoluta necessidade pelos motivos, já que toda ação se dá em um tempo e em um lugar determinados. Seria uma contradição? Não. Significa dizer que a determinação da ação por motivos consiste na ocasião em que um ato em si mesmo livre se efetiva no tempo e no espaço "como exteriorização de nosso ser autêntico e pelo qual fomos feitos responsáveis" (SCHOPENHAUER, 1877, cap. 19, item 8, p. 259) ${ }^{9}$. Tal determinação consiste no ato da vontade considerado segundo o princípio de razão, não por ele mesmo, cuja possibilidade está sempre lá como que à espera de uma oportunidade para se fazer visível, exprimindose no corpo ou na consciência. Conforme citado de início, "as circunstâncias, os destinos, os acontecimentos levam os caracteres à exteriorização da própria essência”, mas “apenas dos caracteres origina-se a ação, da qual procedem os acontecimentos". A ação é sempre livre naquilo que a suporta, a livre manifestação do querer, embora sejam as circunstâncias e motivos apresentados pelo intelecto ao sujeito que lhe deem, em determinados tempo e 
lugar, a oportunidade de se mostrar. Aqui, o intelecto não é necessariamente deliberativo, mas o instrumento (em si mesmo indiferente) pelo qual motivos são apresentados ao sujeito do desejar (Subjekt des Willens). É notável, portanto, que Schopenhauer oferece um fundamento para a moralidade, mas não para a ação tomada em si mesma, como expressão imediata do caráter, de maneira que a lei da motivação "de nada serve" senão para o conhecimento teórico das aparências e, nessa via, como oponente do "otimismo moral" em geral e, em particular, do racionalismo na Ética.

Para cada exteriorização da Vontade, para cada ato isolado seu neste tempo, neste lugar, é possível demonstrar um motivo do qual este ato, sob a pressuposição do caráter do homem, tinha de se seguir necessariamente. Mas que ele tenha tal caráter, que ele queira em geral, que dentre tantos motivos exatamente este e não outro, sim, que algum tipo de motivo movimente a Vontade, eis aí algo ao qual não se pode fornecer fundamento algum. [...] exteriorizações são ocasionadas por ação vinda de fora, enquanto a qualidade essencial mesma, ao contrário, não é determinada por coisa alguma externa a si, portanto é inexplanável. (SCHOPENHAUER, 2005, §24, p. 185) ${ }^{10}$

Assim, quando digo - podendo causar espanto - que não há fundamento para a ação, refiro-me não à dimensão "física", exterior, cujo fio causal se pode percorrer até a imputabilidade jurídica ou psicológica, mas à metafísica-moral, íntima e insondável pelo próprio agente na maioria das vezes. Eis o que costuma desconcertar os estudiosos, a saber, que não apenas possamos ser, mas que somos responsáveis sem qualquer justificativa. Não pelos atos propriamente, vistos de fora, mas pelo querer que se deixa mover pelos motivos que determinam as ações e aparece nesses atos. Somos os únicos autores de nós mesmos, como que injustificadamente autolançados no mundo, sendo isso que significa a liberdade de ser, não de agir. Esse "ser" não é a Vontade universal como algo que não nos concerne, mas a vontade que cada um de nós é. O que também parece desconcertar os estudiosos é que ainda não seja ninguém "aquele" que determina o caráter, sequer um sujeito (no que só pode se converter por esse ato originário), mas que a livre determinação do caráter seja precisamente o que se manifesta no tempo e no espaço como alguém. Significa dizer: somos manifestação de uma livre vontade que se afirma e, desse modo, embora responsáveis, não temos o menor poder sobre aquilo que já sempre somos, nem temos como saber o porquê de nos termos feito tal como nos fizemos, esta vontade individual cujas determinidades essenciais se desdobram no tempo e no espaço segundo as causas 
(motivos) que se lhe apresentam como objeto para o sujeito que cada um de nós é. Poder escolher o querer é justamente a hipótese do livre arbítrio, veementemente refutada por Schopenhauer. Podemos alterar nossa aparência no tempo, mas não nosso ser atemporal.

O conceito de liberdade moral, por sua vez, é inseparável do de origina[riedade] [Ursprünglichkeit]. Com efeito, a ideia de que um ser seja obra de um outro pode ser dita em palavras, mas decerto não apreendida pelo pensamento, tampouco que seja [em tal caso] livre com relação a seu querer e seu agir. [...] Como o homem é, assim ele é obrigado a agir: portanto, culpa e mérito são inerentes à sua essência e ao seu ser, não às suas ações particulares. Por isso o teísmo e a responsabilidade do homem são inconciliáveis, justamente porque a responsabilidade recai sempre sobre o autor do ser [...] O ser livre deve ser também originário. Se a nossa vontade é livre, ela também é o ser originário [Urwesen], e vice-versa. [...] a própria teoria da necessidade dos atos de vontade exige que a existência e a essência do homem sejam elas mesmas obras de sua liberdade, ou seja, de sua vontade, enfim, que a vontade possua aseidade [Aseität]. Pressupondo-se o contrário, como se mostrou, cairia qualquer responsabilidade, e o mundo moral, como o físico, seria uma pura máquina [...]. (SCHOPENHAUER, 2003, §118, p. 311-312; 1894, §118, p. 222-223. Tradução levemente modificada)

Exceto por ter levado o princípio de razão suficiente para além de sua jurisdição, Leibniz $(2004, \S 32$, p. 137) permanece correto ao notar que a admissão de que para todo fato há uma razão suficiente não implica que tal razão seja conhecida. Para Schopenhauer, o próprio princípio de razão exige do intelecto o preenchimento de tais lacunas entre querer e agir. Certamente essa expressão do caráter pode ser e ordinariamente é mascarada, seja quando se engana os outros, seja quando se engana a si mesmo. Schopenhauer oferece fartos exemplos de como motivos abstratos produzem ações terríveis e mesmo corrompem os indivíduos, mas isso se dá também na medida em que o indivíduo ignora seu próprio caráter, tornando-se na mesma medida suscetível a se deixar levar por ideias absurdas. ${ }^{11}$ Para o bem como para o mal, a sociedade se torna possível apelando-se ao egoísmo direcionado ao interesse comum, tática de que o Direito parece ser a forma mais acabada.

Como foi dito há pouco, a aquisição de um caráter não é o mesmo que a formação de um caráter. Aquele que adquire um caráter tampouco formou a si mesmo, antes descobriu quem é e o que pode fazer, utilizando-se de seu intelecto de maneira a satisfazer o interesse pessoal e assim promover o próprio bem-estar. ${ }^{12}$ Como também devo ter deixado claro, isso não pode significar uma resposta ao pessimismo moral, pois envolve o interesse particular e ainda assim de modo problemático, pois são raros aqueles capazes de 
ter suficiente lucidez sobre seu próprio caráter a fim de reconhecer e formular as máximas que lhe sejam conformes. Nesse sentido, pode-se opor limitações insuperáveis à sugestão de que a sabedoria de vida encerre em si um "otimismo prático", do mesmo modo que a possibilidade de superação do caráter pela negação da Vontade ou sua mortificação não parecem ser, nelas mesmas, morais em sentido estrito, ainda que constituam objeto de interesse para a Ética. ${ }^{13}$ As dificuldades e o curto alcance próprios à doutrina do caráter adquirido parecem justificar, por ser mais "realista", a sugestão de que se trate aí de um “pessimismo pragmático", tal como defende Debona $(2016 \mathrm{~b})^{14}$.

A proposta de Debona segundo a qual se deve compreender a eudemonologia como movida por um pessimismo pragmático parece, de fato, uma muito apropriada alternativa, que, no entanto, pode consistir não em uma complementação ao assim chamado "pessimismo metafísico", de que parece derivar, mas sim em uma resposta ao pessimismo antropológico, isto é, como um "modo de lidar" com a realidade humana. O pessimismo pragmático diz respeito ao uso do intelecto e das próprias forças em uma direção determinada, como a adequação de meios a fins, sem, no entanto, perder de vista os males insuperáveis inerentes à vida e ao convívio social. Pelo contrário, admite-se o mal como uma realidade objetiva perante a qual o indivíduo deve se posicionar pragmaticamente, evitando sofrimentos desnecessários. Sua fonte é completamente empírica e prescinde de especulações metafísicas. Por exemplo, a morte é tida como um mal, mas se tratando de um mal inevitável, é necessário conviver com ele e aceitá-lo na medida em que se encontra fora de nosso poder impedi-lo, não sendo de modo algum necessário ou mesmo pertinente questionar-se acerca do que seja a morte ou a própria vida. ${ }^{15}$ Nesse sentido, além de Schopenhauer aconselhar, do ponto de vista da sabedoria de vida, a não perturbação com a morte, também demonstra, do ponto de vista estritamente racional, a irracionalidade do temor à morte, fato que não atinge nosso ser em si, mas tão somente o fenômeno, nossa aparência para outrem e para nós mesmos.

Vale notar que a ausência de fundamento para o ser em si, que se torna um problema epistemológico, linguístico e moral, encontra aqui a sua consequência positiva, o que, por sua vez, insisto, não significa por si só uma brecha para o otimismo. Do ponto de vista do em-si, nascimento e morte não têm realidade e a razão pode descobri-lo independente dos sentimentos que se tenha a respeito. Ou seja, em última análise, a morte não é um mal verdadeiro, podendo haver um encontro entre experiência pessoal e especulação. 
Acontece, todavia, que esse sentimento a respeito da morte, por exemplo, dá o tom do pessimismo, mas estimar a morte como um mal se revela como uma irracionalidade. Enquanto estimativa, o pessimismo não é uma doutrina, mas um sentimento, portanto, uma espécie de não-saber, algo irredutível às atividades intelectuais. Se o mal no mundo, em sua objetividade, é um mal para o sujeito que assim o julga, o pessimismo ele mesmo deve ser relativizado, não sendo à toa que a sabedoria de vida possa parecer "otimista" relativamente àquilo que objetivamente aflige a humanidade, uma vez que possa estar ao alcance de alguém não se deixar abater por isso e, por esse meio, tornar sua vida algo melhor. Assim, o problema reside no fato de que a necessidade de adequação das ações à vida supõe a recusa daquilo que está implicado no fato de viver e devemos aprender a tolerar, para o nosso próprio bem. Dito de outro modo, uma má avaliação da vida, oriunda de um sentimento de desagrado, é inerente à tentativa ou ao mero desejo de viver o melhor possível, ${ }^{16}$ sendo necessário demonstrar se a vida é mesmo má e, em caso positivo, para quem e sob que aspecto. Aqui, a meu ver, se detém o escopo do sugerido pessimismo pragmático, restando ainda considerar se, de fato, ele responde ou pode prescindir do pessimismo antropológico, em prol do metafísico, ponto no qual me concentrarei adiante a título de complemento necessário, já que o problema moral diz respeito, antes de tudo, ao mundo humano.

Vale, por fim, insistir que a sabedoria de vida não mitiga o pessimismo moral, muito embora a bondade de coração seja possível, o que, aliás, independe da aquisição de um caráter, pois se trata de uma bondade inata. Bons seres humanos parecem ser a minoria, mas existem. Não é, portanto, esse o problema, mas sim a impossibilidade de uma formação do caráter, restando apenas uma adequação de si mesmo ao mundo, na medida em que isso se encontrar de acordo com as forças do agente, com seu caráter. Interessante, todavia, é que Schopenhauer faça uma aposta na moralidade e mesmo na consciência do sofrimento como inerente à vida. À luz do conhecimento, é possível encontrar nas dores do mundo o sentido moral da existência, o que não se obteria na ausência de sofrimento. Aquele que impõe o sofrimento a outrem e não é capaz de senti-lo em si não tem como vislumbrar que, com sua maldade, faz mal a si mesmo, uma vez que se encontra cego pelo princípio de individuação e obstinadamente apegado à própria pessoa. A insuperabilidade do pessimismo moral se deve ao caráter incorrigível do coração. Eis o que torna o pessimismo moral um problema metafísico, mas relativo à natureza do mundo ou apenas 
à natureza do humano? De todo modo, enquanto problema metafísico, parece irredutível ao pessimismo epistemológico, muito embora sua demonstração, como vimos de início, dependa dele. Isso porque, apesar de o intelecto ser limitado, é dotado de imensa plasticidade, ao contrário do "coração", sede do caráter e da vontade. Dizer que a natureza do mundo ou do homem seja má deriva teoricamente do que se pode dizer da relação entre a coisa-em-si e o fenômeno, mas isso não é o mesmo que dizer que o mundo é mau ou a humanidade é perversa porque seu ser-em-si é, como tal, incognoscível. Ainda que o caráter fosse conhecido suficientemente, como o é supostamente pelo sábio, é por razões de ordem metafísica que não pode ser alterado: a determinação do caráter não se dá no tempo, sendo antes a entrada do indivíduo, como tal, na temporalidade, conforme fica claro no MVR I, §55. A possibilidade de autoconhecimento da Vontade não resolve nem minimiza o problema da reforma do caráter que já sempre se tem transcendentalmente determinado como condição da existência. No que concerne ao fato de ser, na maioria dos casos, perverso, o caráter só pode sê-lo na medida do egoísmo natural, presente em inúmeros graus na Natureza.

Assim, o dilema moral se vê estreitamente vinculado ao fato de que só conhecemos nosso próprio caráter mediante sua faticidade, não importando o quão ele nos agrada ou desagrada, mas não se reduz a isso. A faticidade não se aplica apenas ao essencial, mas também ao elemento inessencial do caráter, relativo ao tempo e ao lugar em que se manifesta, pois o caráter empírico "tem de expor exatamente o caráter inteligível, na medida em que este se adapta faticamente em sua objetivação ao estofo previamente dado das circunstâncias" (SCHOPENHAUER, 2005, §28, p. 225). O fato de já sempre sermos aquele que somos, de modo ineludível e irreparável, é o ponto de encontro entre a doutrina schopenhaueriana e as ditas filosofias existencialistas, também consideradas "pessimistas" por muitos. Contudo, ao existencialista permanece muito claro que a faticidade não está legitimamente sujeita a juízos de valor com relação a seu caráter ótimo ou péssimo - o fático é o que é, sempre significado segundo uma conjuntura que, no entanto, em nada afeta o seu já-ser.

Deixamos com isso, por enquanto, o elemento transcendental e suas interdições rumo ao empírico. A fim de abordar o problema da má natureza, cabe iniciar pelo caso da natureza humana antes de ampliar o escopo para a natureza em geral, o que, no entanto, os limites do presente artigo não permitirão que seja feito, senão a partir do olhar humano. 


\title{
Pessimismo antropológico
}

O que aqui denomino "pessimismo antropológico" deve ser entendido como o modo mais compreensivo de se tematizar a questão do sofrimento humano, de que tanto se ocupa Schopenhauer em suas exposições. Considero-o mais poderoso do que o pessimismo pragmático na medida em que não envolve uma atitude individual, mas uma valoração objetiva com relação ao mundo humano. Em primeiro lugar, deve-se admitir que a negação da vontade e a sabedoria de vida são casos de exceção cuja possibilidade não basta para amenizar o diagnóstico geral da espécie. Desse modo, passemos à regra, seguindo a hipótese de que o problema do mal no mundo reside na natureza humana.

Debona toca no assunto, mas prontamente recusa que o "pessimismo schopenhaueriano" consista em um pessimismo antropológico, nos seguintes termos, citando Sobre o fundamento da moral, de Schopenhauer:

\begin{abstract}
"A motivação principal e fundamental, tanto no homem quanto no animal, é o egoísmo, ou seja, o ímpeto para a existência e o bem-estar" (Schopenhauer, 1840, p. 120). Não se trata, então, de um "pessimismo antropológico", pois apesar de o egoísmo animal não consistir em um "interesse próprio" (Eigennutz) e planejado, ele ainda seria um "amorpróprio" (Selbstsucht). Na natureza humana, porém, o egoísmo interesseiro não conhece limites: "Cada um traz em si o único mundo que conhece e de que sabe como sua representação, e por isso esse mundo é o seu centro [...]. É assim que este egoísmo, que está entre um homem e outro como uma larga cova, cresce sempre mais" (ibidem, p. 122). Ao sublinhar essa "grandeza do egoísmo" (die Größe des Egoismus), Schopenhauer chega à nefasta consideração de que "alguns homens seriam capazes de assassinar um outro só para engraxar suas botas com a gordura dele" (ibidem, p. 124). (DEBONA, 2016b, p. 788) ${ }^{17}$
\end{abstract}

O "pessimismo antropológico" não é detalhado no artigo, mas podemos partir de sua recusa por Debona, muito embora suas palavras exibam uma apreciação bastante depreciativa da espécie humana, como aquela que é capaz de matar um semelhante apenas para usar a gordura em suas botas, ou seja, para nada de útil à sobrevivência, à perpetuação, à melhoria. Ao que parece, Debona se apoia no fato de que, a despeito da indicada diferença de grau, o egoísmo veemente, que mais fortemente produz o mal alheio, é comum a humanos e demais animais, e que tal egoísmo seria o Selbstsucht. Nesse caso, os animais seriam corresponsáveis pelo mal no mundo, a ponto de o mesmo não poder ser remetido 
exclusivamente ao humano como, supõe-se, faria o pessimismo antropológico. De fato, Schopenhauer escreve:

[...] pode-se bem chamar os animais de egoístas, mas não de interesseiros. Este egoísmo é ligado o mais estreitamente possível, tanto no homem como no animal, com o âmago e o ser mais íntimo deles e lhes é propriamente idêntico. [...] O egoísmo, de acordo com a sua natureza, é sem limites [...]. (SCHOPENHAUER, 2001, §14, p. 121)

Observo, de passagem, que Schopenhauer exclui a palavra "Selbstsucht", preferindo denominar egoísmo (Egoismus) a afirmação da vontade entendida como afirmação do amor-de-si, estando presente em inúmeros graus na Natureza, porém sempre sem limites. Afinal, de acordo com a veemência da afirmação, faz-se o máximo pelo benefício próprio, e, se nos animais não se encontra interesse próprio, é por que lhes falta egoidade, agindo por instinto e não pelo amor de um eu. Em si, nenhum egoísmo pode ter limites. Seus limites são, em verdade, extrínsecos, pertencem - como todo limite - ao mundo objetivo, ou seja, variam segundo a medida das capacidades do organismo cuja autoafirmação expressa. No caso humano, tais capacidades são extremas em virtude da faculdade da razão, que produz e pode aderir a toda espécie de motivações abstratas, sem mencionar o próprio surgimento da autoconsciência, identificada como um Eu irredutível à espécie, fonte propriamente dita do que se pode denominar "interesse pessoal", ou "amorpróprio", i.e. desejo de vantagem. No mesmo parágrafo citado por Debona também lemos na sequência: "A palavra alemã 'Selbstsucht' leva a um falso conceito, próximo de doença" (SCHOPENHAUER, 2001, §14, p. 120). A palavra Selbstsucht significa, literalmente, "vício de si”, denotando uma espécie de patologia psíquica que produz uma fixação do indivíduo em si mesmo, desse modo não aplicável a animais. ${ }^{18}$

Embora essas observações não invalidem o que diz Debona - pelo contrário, o reforçam no sentido da pretendida coparticipação dos animais no mal deste mundo -, não se pode desconsiderar que o Selbstsucht consiste em um caso particularíssimo de egoísmo, ou egocentrismo. Isso considerado, a ampliação do egoísmo (natural) aos animais não elimina a justificável objeção de que o egoísmo, dentre os animais, não tem implicações morais, apenas físicas. Se o sacrifício de um animal que matou a outro ou a um humano é determinado judicialmente, deverá sê-lo por questões de segurança ou saúde pública, não por ter sido considerado ato criminoso, sendo digno de nota que o inverso não se dá: a 
morte de um animal por um homem, sem reconhecida justificativa, e mesmo os maustratos são passíveis de sanção legal. Desse modo, o egoísmo natural também produz males objetivos, mas parece problemático recusar a noção de pessimismo antropológico amparando-se apenas nisso.

O problema fundamental do egoísmo humano, que adquire dimensão moral, reside em que é sediado em uma egoidade interesseira, que não quer para si apenas o necessário ou o suficiente à sobrevivência, mas, sobretudo, não quer para outrem o que não pode ter para si ou não com exclusividade. Não é preciso, ademais, ser mau ou cruel para sentir inveja, por exemplo, ou ambição para conquistar, mesmo com honestidade, o que é possuído por outrem, bem como para sofrer com o fracasso de seus esforços. Tudo isso que, de humano, se encontra além do egoísmo como amor-de-si, natural, deve ser antes remetido a uma forma de egoísmo somente possível ao homem: o amor-próprio. ${ }^{19}$ Conforme uma importante distinção feita por Rousseau, o amor-próprio vai além do instinto de conservação, em si mesmo amoral - que ele preferia denominar "bom" pelo simples fato de ser natural, não corrompido, portanto, sempre destituído da intenção consciente de causar dano -, consistindo em um sentimento produzido pela razão mediante a comparação entre si e os outros. O amor-próprio ama o que possui e quer possuir, consistindo já em uma desnaturação, por isso considerado mau. Enfim, insistindo na especificidade da forma assumida pelo egoísmo no mundo humano se percebe o alcance de suas consequências sobre a possibilidade de convívio entre os humanos, sobre a relação destes com seu meio e, portanto, para o surgimento do mal moral, até então ausente na Natureza. Não é por outra razão que se coloque sobre as costas do homem a culpa pelo Pecado Original ou a responsabilidade pela Salvação.

Diferente do pessimismo moral, que vimos derivar (teoricamente) do pessimismo epistemológico, sempre segundo uma crítica da razão, ou seja, por argumentos antes de tudo formais, o pessimismo antropológico se assenta sobre o caráter empírico da espécie. No contexto do trecho comentado por Debona, como em diversos pontos da obra de Schopenhauer, vemos a alusão à célebre fórmula hobbesiana: "bellum omnium contra omnes". Uma dessas ocorrências deve ter relevância significativa para nós nesse momento, encontrando-se no oitavo item do capítulo 19 dos complementos ao MVR: "Movido por secreta inclinação, todo mundo elege para seu relacionamento mais íntimo alguém em relação a quem ele seja um pouco superior em termos de entendimento, pois só com uma 
pessoa assim que ele se sente à vontade" (SCHOPENHAUER, 2014a, p. 343). A fim de corroborar essa afirmação psicológica sobre o caráter da espécie, Schopenhauer evoca nada menos do que as palavras no mais notável pessimista antropológico no tratado De cive: “Toda alegria do coração e todo momento feliz dependem de nós termos alguém com quem possamos nos comparar e pensar o melhor de nós mesmos" (HOBBES apud SCHOPENHAUER, 2014a, p. 343). ${ }^{20} \mathrm{O}$ mesmo diagnóstico foi confirmado por filósofos tão distintos entre si como Rousseau e Nietzsche, tendo lugar marcante em suas obras. Se ampliamos seu escopo, entendemos que a história do pensamento encontra um lugar comum, um ponto pacífico, com relação à imensa dificuldade que o ser humano tem para se alegrar com a felicidade alheia, a não ser que ele mesmo seja sua causa ou pelo menos participe dela. A exceção a essa regra é sublinhada por Schopenhauer como um "caráter sublime”, ao fim do $\$ 39$ do MVR I:

O caráter sublime, por exemplo, notará erros, ódio, injustiça dos outros contra si, sem no entanto ser excitado pelo ódio; notará a felicidade alheia, sem no entanto sentir inveja; até mesmo reconhecerá as qualidades boas dos homens, sem no entanto procurar associação mais íntima com eles; perceberá a beleza das mulheres, sem cobiçá-las. [...] Pois, em seu próprio decurso de vida com seus acidentes, olhará menos a própria sorte e mais a da humanidade em geral, e, assim, conduzirá a si mesmo mais como quem conhece, não como quem sofre. (SCHOPENHAUER, 2005, p. 280)

Quando, então, refiro-me a um pessimismo antropológico, refiro-me a essa dificuldade especificamente humana que se encontra na raiz de todas as relações empíricas e fornece, em última instância, um indicativo bastante seguro acerca da qualidade do caráter de uma pessoa. Não se pode, certamente, chamar alguém de "má pessoa" por ter essa regra aplicável a si, mas certamente é uma boa pessoa aquela a quem isso não se aplica. Veja-se o que diz o próprio Schopenhauer quanto a isso:

Pois a bondade de coração [Güte des Herzens] é uma qualidade transcendente, pertence a uma ordem de coisas para além desta vida e é incomensurável com qualquer outra perfeição. Onde está presente em elevado grau, torna o coração tão grandioso, que envolve o mundo, de tal forma que agora tudo está nesse coração e nada mais é exterior a ele; pois a bondade de coração identifica todos os seres consigo mesma. Com o que, também, pratica com todos os outros aquela ilimitada indulgência que, via de regra, cada um tem apenas consigo mesmo. Essa pessoa não é capaz de inflamar-se: inclusive, quando seus próprios defeitos físicos 
ou intelectuais suscitam a maliciosa zombaria e o desprezo dos outros, em seu coração repreende apenas a si por ter sido a ocasião de tais exteriorizações, e, por conseguinte, continua, sem constranger-se, a tratar aqueles da maneira mais afável possível, esperando confiantemente que se desvencilharão dos seus erros a seu respeito e também nele[s] reconhecerão a si próprios. Comparad[o] a tal pessoa, que é o engenho e o gênio? (SCHOPENHAUER, 2015, cap. 19, p. 281) $)^{21}$

Essa passagem inspiradíssima, embora longa, é digna de ser transcrita na íntegra. Não é, contudo, comumente referida, o mesmo se aplicando à anteriormente citada, a qual se faz ainda mais relevante ao destacar a medida da contribuição do indivíduo para o sofrimento no mundo e para o seu próprio. Aqui se mostra uma apreciação de uma vontade boa, expressão que Schopenhauer convenientemente não utiliza, senão por essa metafórica bondade de coração ou alusivamente como bondade de caráter. Deve-se destacar, em recordação do que já foi dito sobre a impossibilidade de formação do caráter, a completa independência da bondade autêntica com relação à inteligência. Nada há aqui de uma conformidade em vista do próprio bem, tanto menos uma compaixão, mas uma disposição benévola inata que sequer necessita de uma visão mística da unidade da Vontade para "abraçar o mundo" ou para que esse mundo entre em seu coração. Pelo contrário, parece ser essa bondade a condição para uma ascese que geralmente sequer se realiza. $O$ sofrimento não desempenha aqui nenhum papel, seja o próprio, seja o do mundo, pois nada há aqui de inessencial ao caráter. O sentimento de injustiça não leva a um orgulhoso “oferecer a outra face", não move o cometimento de injustiça contra si mesmo, não quer dar testemunho da própria superioridade sob nenhum aspecto. O sentimento de injustiça, naquele que não toma o outro como oponente, mas como igual, neste caso particularíssimo, produz uma confirmação da necessidade de expor a bondade que guarda em si, não no sentido de um exibicionismo para mostrar aos demais que se enganaram a seu respeito e então se retratem, mas de um manter-se firme pensando ter sido causa de uma incompreensão. Pode-se evocar, com correção, que a compaixão admite inúmeros graus, em geral inconscientes, de identificação com o outro, como quando me sinto mal ao prejudicar a outrem, mas, aqui, trata-se apenas da boa disposição considerada em si mesma, como aquilo "que pertence a uma ordem de coisas para além desta vida". Enfim, vale ressaltar a conclusão que se anuncia aqui: a "má natureza humana" não é assim tão natural no sentido de uma perversão universal da espécie, mas um subproduto do modo de operação da consciência humana na sua relação consigo mesma, ou seja, sua tendência à 
elevação do eu contra o não-eu. Em outras palavras, o problema antropológico não decorre tanto do modo de ser objetivo da espécie quanto da sua excepcional faculdade de representação abstrata, que leva o indivíduo humano demasiadamente para fora de si e de seu presente.

Parece que Schopenhauer, enquanto pessoa, não atendia bem a sua exigente concepção de bondade, sendo antes animado por um decidido orgulho acerca de quem ele mesmo era. Não obstante, são significativas e úteis ao propósito presente as palavras dos manuscritos póstumos citadas por Safranski na biografia de Schopenhauer:

Todas as ocasiões em que me senti infeliz ao longo da vida sempre foram provocadas principalmente por causa de uma méprise, a saber, um erro cometido não por mim, mas por alguém com relação à minha pessoa, por me tomarem por algo diferente do que sou, alguém simplesmente disposto a se lamentar agora por causa de suas desgraças [...]. Mas embora tudo isso tenha acontecido comigo, eu nunca fui nada disso; todas essas figuras não foram mais do que o tecido com que foi costurado um capote que usei durante algum tempo e logo depois troquei por outro. Quem sou eu, então? Sou este que escreve aqui? Nada disso, eu sou aquele que escreveu $O$ mundo como vontade e representação e que apresentou uma solução para o grande problema da existência. (SCHOPENHAUER apud RAMOS, 2014, p. 7)

Seriam estas as palavras de um pessimista? Jamais de um derrotista, pelo menos. Emerge aqui, se pensamos nos Aforismos de sabedoria de vida, que o que alguém representa tem um papel muito decisivo quando se trata de viver em meio a outrem. Nesse caso, saber quem se é, com a devida lucidez, é essencial para que adequadamente se lide com aqueles que, de nós, dão atenção apenas ao que não nos é essencial. Para isso é requerida força de caráter, a verdadeira "força de vontade", que não deve ser confundida nem com obstinação nem com esperança ou excesso de autoconfiança, sendo, pura e simplesmente, lucidez e sinceridade consigo mesmo. A força de vontade, ou de caráter, deve se referir àquele que frequentemente sabe fazer das coisas antes "objetos de reflexão do que de entusiasmo e aborrecimento". ${ }^{22}$ Deve-se, como diz Schopenhauer no mesmo contexto, manter a cabeça no lugar. 


\section{Considerações finais}

Em última instância, o pessimismo moral coloca um problema sem solução, mas tal problema só existe se temos em consideração o bem-estar como um projeto de vida legitimamente realizável. Logo, trata-se de reconhecer que o que não tem solução não pode ser considerado um problema legítimo. Similarmente, o pessimismo epistemológico coloca um problema sem solução, mas tal problema só existe se temos em consideração a possibilidade de conhecimento de algo que não pode ser legitimamente conhecido, em nada afetando o ser humano ordinário, que, aliás, vira-se muito bem no mercado ideológico, sempre a lhe oferecer "razões" e "explicações" sobre tudo. Quanto a isso, a indisposição geral do ânimo comum para tais problemas fala por si. O pessimismo pragmático sugerido por Debona, por sua vez, nos orienta a dirigir nossa atenção à realidade objetiva, ajuizada como sendo uma natureza má. Nesse ínterim, serve como possível remédio para quem precisa dele, sem necessariamente alçar-se a um diagnóstico filosófico sobre a natureza do mundo como tal.

Fica bastante claro, quem sabe a essa altura já autoexplicativo, que a perversidade humana tem muito de seu significado oriundo do modo como cada indivíduo se posiciona em face um do outro: como um adversário ou como um semelhante; como alguém a ser transformado a fim de atender a nossa expectativa ou a ser respeitado naquilo que é e não pode deixar de ser. Evidentemente isso não elimina nem mesmo atenua o diagnóstico genérico sobre a perversidade humana, nem o pretende. Se o pessimismo pragmático não é resposta suficiente ao pessimismo antropológico, na medida em que este não está comprometido com valorações subjetivas, mas com a experiência social humana, a ideia de um pessimismo antropológico chega a confirmar que o problema moral do sofrimento deve, sim, ser remetido àquilo que determina o indivíduo em seu modo de ser: uma vontade livremente autodeterminada que, na medida de sua cegueira, é levada a fazer caso apenas de si mesma, podendo se tornar capaz de destruir um mundo inteiro em nome de sua exclusiva autoconservação. Em verdade, é o que a Vontade faz a cada instante - enquanto una e indivisível, nada se ganha nem se perde; porém, fenomenalmente fragmentada, permanece em eterno conflito interno. Ora, o conflito interno só se dá do ponto de vista da pluralidade das aparências assumidas pela coisa-em-si, que, nela mesma, deve ser admitida 
como absolutamente concordante consigo mesma, o que Schopenhauer reiteradamente diz no livro II do MVR.

Vimos ao longo desta exposição que os limites de nosso conhecimento nos impedem de julgar a coisa-em-si, bem como de transformá-la. A onipresença do mal no mundo é um fato, mas, na condição de fato, é ao mesmo tempo incontornável se não individualmente e sua elucidação metafísica nos diz que concerne tão somente à vida dos indivíduos. Em verdade, todo mal é fissico ou oriundo de relações físicas a que as múltiplas aparências da Vontade estão a cada vez submetidas na medida de sua cegueira. O mal não é atributo da Vontade - ou melhor, da coisa-em-si ela mesma -, mas remissível à sua cegueira originária. ${ }^{23}$ A culpabilidade advém da faticidade de um livre querer que se efetiva produzido um mal que igualmente poderia não existir. Poderia porque, sendo livre, a Vontade não pode ser dita compelida a se afirmar, como o prova a possibilidade de autonegação. 


\begin{abstract}
Notas:
${ }^{1}$ Doutor em Filosofia. Professor Adjunto no Departamento de Filosofia da UFRN e membro permanente do Programa de Pós-Graduação em Filosofia da mesma universidade (Natal, Brasil). Atua principalmente nas áreas de Metafísica e História da Filosofia em geral. Em seu trabalho recente, dedica-se à filosofia de Schopenhauer e destacam-se artigos e conferências sobre o amor, liberdade e outros temas de interesse nas filosofias da existência. Membro do núcleo de sustentação do GT Schopenhauer da ANPOF e líder do Grupo de Pesquisa Metafísica Contemporânea. E-mail: dax@cchla.ufrn.br.
\end{abstract}

2 "Não querer a vida/existência" não é, para Schopenhauer, o mesmo que querer morrer. Conhecida sua tese de que no suicídio se exprime um querer a vida, remeto o leitor ao texto "A afirmação da vontade-de-viver no suicídio: a vida como representação" (MORAES, 2010b), já que o tema excede o escopo do presente artigo.

${ }^{3}$ V. p. ex. SCHOPENHAUER, 2015, cap. 22, p. 333 et passim; 2014a, cap. 22, p. 405 et passim.

${ }^{4}$ Da negação da vontade, porém, não tratarei aqui. Além de considerar os limites da presente exposição, em vista do que se deve evitar desvios, a questão do "pessimismo moral", como se poderá perceber, prescinde da possibilidade da negação da vontade, sequer sendo aconselhável começar daí como muitas vezes se faz. Em síntese, a tese de que o mundo seja algo que seria melhor não existir e de que o querer viver que nele se manifesta merece ser negado pertence a um diagnóstico que em nada influi na constatação de um pessimismo moral, pelo qual a Ética consiste em uma teoria que visa ao esclarecimento do intelecto, não podendo jamais servir à correção do caráter, ou reforma do coração. Desse modo, restrinjo-me a brevíssimas considerações no único interesse do que se pretende expor neste artigo.

${ }^{5}$ Não se trata de uma petição de princípio ou de uma circularidade pois a justificação moral da metafísica não depende de que não possamos conhecer o que se encontra para além do princípio de razão, mas tal justificação envolve um salto sem o qual qualquer explicação objetiva padece de uma lacuna imperdoável, que é a de tomar o que é apenas para o sujeito como aquilo que é em si mesmo, cognoscível ou não. O mundo não pode ser conhecido a partir de si mesmo e seu modo de aparecer - tal pretensão é ingênua -, sendo a metafísica autêntica o modo de pensá-lo independentemente de suas leis, empreitada em que Schopenhauer se mostra mais radical do que Kant. Uma vez admitida uma metafísica, a ela deve pertencer a possibilidade da liberdade e, portanto, da responsabilidade. Sendo assim, não se trata de defender uma metafísica segundo pressupostos metafísicos e a admissão não dogmática de uma metafísica a posteriori se converte a um só tempo em uma exigência da razão - como Kant o admitiu - e um resultado a priori da crítica da razão, segundo a qual todo fenômeno supõe uma subjetividade transcendental que o representa.

${ }^{6}$ Cf. passagem paralela no capítulo 18 do MVR II (SCHOPENHAUER, 2014a, p. 301-302; 2015, p. 239240). São textos fundamentais para que não se superestime a possibilidade de conhecimento da coisa-em-si, pois revelam muito mais do que a mera distinção entre o si-mesmo como tal, formal ou concretamente considerado, e o eu abstrato.

${ }^{7}$ V. p. ex. SCHOPENHAUER, 2014a, cap. 19 (item 6), p. 337; 2015, cap. 19 (item 6), p. 270.

${ }^{8}$ V., p. ex., "Caráter, liberdade e "Aseität": sobre a assimilação das noções de caráter inteligível e caráter empírico de Kant por Schopenhauer" (DEBONA, 2016a), que traz uma compreensiva abordagem da relação entre a ética schopenhaueriana e a de Kant e, nesse ínterim, menciona o impasse relativo à conciliação entre liberdade e necessidade, para cuja solução aponto aqui, como já fizera antes em mais detalhe (MORAES, 2011).

${ }^{9}$ Cf. SCHOPENHAUER, 2014a, p. 346; 2015, p. 278.

${ }^{10}$ V. tb. p. ex. sobre as determinações essenciais e inessenciais: §26, p. 201; §28, p. 224. 
${ }^{11}$ Uma análise do caso da religião, articulado de modo bastante conciso com os temas da liberdade, do caráter, do ateísmo, da responsabilidade e de nossa "necessidade metafísica", pode ser encontrada em "Sobre a impossibilidade do aprimoramento moral pela religião" (MORAES, 2017a).

${ }^{12}$ Aqui se faz referência à tese do caráter adquirido, que aparece sob esta forma privilegiadamente no $§ 55$ do MVR I e, em verdade, é exposta em todas as suas nuances nos Aforismos de sabedoria de vida. Consiste no conhecimento refletido sobre o próprio caráter, pelo qual se torna possível uma conduta não errática, mas uniforme na vida. Portanto, a falta disso implica uma "ausência de caráter" no sentido de que o indivíduo como que se comporta ao sabor das circunstâncias e inclinações imediatas, inconsistentemente.

${ }^{13}$ Sobre essas alternativas e sua precariedade no que diz respeito à realização da moral no mundo, ver o artigo "O caráter inteligível como fundamento ontológico para a sabedoria de vida" (MORAES, 2016).

${ }^{14}$ Como seu artigo se concentra em um diálogo interessante com a tese do chamado "pessimismo metafísico", tema que excede o presente tópico, limito-me a mencionar de modo geral a sua noção de "pessimismo pragmático", que consiste em um modo particular de se relacionar com o pressuposto mal intrínseco à existência, uma adequação do costume.

${ }^{15}$ Por essa atitude é possível vincular a sabedoria de vida às considerações que Schopenhauer faz sobre estoicos e cínicos no $§ 16$ e no capítulo 16 dos dois volumes do MVR, respectivamente.

${ }^{16}$ Sobre isso, ver "Mefistófeles e o mundo como vontade: os tipos afirmador e negador, otimista e pessimista, no Fausto, de Goethe" (MORAES, 2015).

${ }^{17}$ A paginação indicada para as citações de Schopenhauer correspondem à da edição brasileira listada nas referências.

${ }^{18} \mathrm{~V}$. comentário etimológico a essa passagem em "O dualismo kantiano e sua crítica por Schopenhauer" (MORAES, 2013, p. 420-421, n. 2), fazendo paralelo entre a terminologia aí empregada e aquela de Rousseau, cuja influência sobre Schopenhauer parece bastante defensável.

19 A tradução brasileira de "Selbstsucht" por "amor-próprio" não parece adequada, mas preserva algo importante, que é a não atribuição dessa forma de egoísmo aos animais irracionais, que compartilham com os humanos um egoísmo mais fundamental, genérico, que é o natural "Egoismus", compatível à noção de amor-de-si.

${ }^{20}$ Citado conforme traduzido na nota 326 , p. 555, no mesmo volume.

${ }^{21} \mathrm{O}$ item 9, a seguir, é dedicado à já mencionada identidade entre caráter (vontade) e coração.

${ }^{22}$ SCHOPENHAUER, 1877, cap. 19, item 4, p. 238: “früher zum Gegenstand der Ueberlegung, als des Eifers und Verdrusses machten".

${ }^{23}$ Sobre a relação entre o mal e a cegueira da Vontade, no sentido que ela não pode ser considerada má em si mesma, ver "A inocência da Vontade" (MORAES, 2017b), a cujo conteúdo se faz referência neste parágrafo. 


\section{Referências}

CIRACÌ, Fabio. Metafisiche del nulla: Schopenhauer, i suoi discepoli e l'inconsistenza del mondo. Consecutio Rerum: rivista critica della postmodernità. Roma, Vol. I, n. 2, abr. 2017, p. 99-114.

DEBONA, Vilmar. Caráter, liberdade e "Aseität": sobre a assimilação das noções de caráter inteligível e caráter empírico de Kant por Schopenhauer. Kant e-Prints.

Campinas, Série 2, v. 11, n. 2, maio-ago. 2016a, p. 32-50. Disponível em: < https://www.cle.unicamp.br/eprints/index.php/kant-e-prints/article/view/672 > . Acesso em: 24 set. 2017.

DEBONA, Vilmar. Pessimismo e eudemonologia: Schopenhauer entre pessimismo metafísico e pessimismo pragmático. Kriterion - Publicação da Faculdade de Filosofia e Ciências Humanas da UFMG. Belo Horizonte, v. 57, n. 135, set.-dez. 2016b, p. 781-802. Disponível em: < http://www.scielo.br/pdf/kr/v57n135/0100-512X-kr-57-135-0781.pdf >. Acesso em: 12 abr. 2017.

KANT, Immanuel. Crítica da razão pura. Trad. Anot. Fernando Costa Matos. 3. ed. Petrópolis: Vozes; Bragança Paulista: EDUSF, 2013.

LEIBNIZ, G. W. Os princípios da filosofía ou a monadologia. Trad. Alexandre da Cruz Bonilha. In: LEIBNIZ, G. W. Discurso de metafísica e outros textos. São Paulo: M. Fontes, 2004. p. 129-149.

MORAES, Dax. Schopenhauer e o mito do pecado original: acerca da vontade como querer-ser. Saberes - Revista Interdisciplinar de Filosofia e Educação. Natal, v. 3, n. especial, dez. 2010a, p. 37-46. Disponível em: <

https://periodicos.ufrn.br/saberes/article/view/875/807 >. Acesso em: 26 set. 2017.

MORAES, Dax. A afirmação da vontade-de-viver no suicídio: a vida como representação. In: REDYSON, Deyve. (Org.). Arthur Schopenhauer no Brasil:

homenagem aos 150 anos da morte de Schopenhauer. João Pessoa: Ideia, 2010b. p. 231 250.

MORAES, Dax. Liberdade e negação da vontade: análise do ser-livre como representação e na angústia. 2011. Tese (Doutorado em Filosofia) - Universidade Federal do Rio Grande do Norte. Natal, 2011.

MORAES, Dax. O dualismo kantiano e sua crítica por Schopenhauer: considerações acerca do caráter analógico da filosofia prática e suas limitações. Princípios: revista de filosofia - Publicação do Programa de Pós-Graduação em Filosofia da UFRN. Natal, v. 
20, n. 33, jan.-jun. 2013, p. 411-447. Disponível em: $<$

https://periodicos.ufrn.br/principios/article/view/7525/5595 >. Acesso em: 12 abr. 2017.

MORAES, Dax. Mefistófeles e o mundo como vontade: os tipos afirmador e negador, otimista e pessimista, no Fausto, de Goethe. In: CARVALHO, Marcelo; DANOWSKI, Déborah; SALVIANO, Jarlee O. S. (Org.). Temas de Filosofia. São Paulo: ANPOF, 2015. p. 160-175.

MORAES, Dax. O caráter inteligível como fundamento ontológico para a sabedoria de vida. Revista Voluntas: estudos sobre Schopenhauer. Rio de Janeiro, v. 7, n. 1, jan.-jun. 2016, p. 186-206. Disponível em:

$<$ http://www.revistavoluntas.com.br/uploads/1/8/1/8/18183055/v7-n1-1-art10-2016moraes_dax.pdf >. Acesso em: 16 jul. 2017.

MORAES, Dax. Sobre a impossibilidade do aprimoramento moral pela religião. In: KLEIN, J. T.; NAHRA, C.; MENEZES, A. B. N. T. de. (Org.). A religião em questão: temas de ética e filosofia política. Rio de Janeiro: Lumen Juris, 2017a. p. 173-183.

MORAES, Dax. A inocência da Vontade. In: Hegel e Schopenhauer. ANPOF, 2017b. (artigo no prelo).

RAMOS, Flamarion Caldeira. Os complementos ao Mundo como vontade e representação. In: SCHOPENHAUER, Arthur. O mundo como vontade e representação: tomo II - complementos. Curitiba: UFPR, 2014. v. 1. p. 5-13.

SCHOPENHAUER, Arthur. Sämtliche Werke. Vol. III. Ed. Julius Frauenstaedt. Leipzig: Brockhaus, 1877.

SCHOPENHAUER, Arthur. Sämtliche Werke in zwölf Bänden. Vol. X: Parerga und Paralipomena, 3. Mit einer Einleitung von Dr. Rudolf Steiner. Stuttgart: J. G. Cotta, 1894.

SCHOPENHAUER, Arthur. Sobre o fundamento da moral. Pref. Alain Roger. Trad. Maria Lúcia Mello Oliveira Cacciola. São Paulo: M. Fontes, 2001.

SCHOPENHAUER, A. Parerga e paralipomena: scritti filosofici minori. Vol. II. Ed. Mario Carpitella. Trad. Mazzino Montinari e Eva Amendola Kuhn. Firenze: Adelphi, 2003.

SCHOPENHAUER, Arthur. O mundo como vontade e como representação: tomo I. Trad. Jair Barboza. São Paulo: UNESP, 2005. 
SCHOPENHAUER, Arthur. O mundo como vontade e representação: tomo II complementos. Trad. Eduardo Ribeiro da Fonseca. Curitiba: UFPR, 2014a. v. 1.

SCHOPENHAUER, Arthur. O mundo como vontade e representação: tomo II complementos. Trad. Eduardo Ribeiro da Fonseca. Curitiba: UFPR, 2014b. v. 2.

SCHOPENHAUER, Arthur. O mundo como vontade e como representação: tomo II. Trad. Jair Barboza. São Paulo: UNESP, 2015. 